\title{
Reusing the Product Oriented Writing to Enhance the First Year EFL Undergraduate Field Independent Students' Writing Achievement
}

\author{
Sujito \\ Department of English Language Education \\ IAIN FITK Surakarta, Indonesia \\ sujito.team@gmail.com
}

\author{
Rina Widjajanti \\ Teacher of Economics MAN 3 Malang \\ Malang, Indonesia \\ rinwidj@gmail.com
}

\begin{abstract}
The study is aimed at proving empirically the significant effect of applying the product oriented writing instruction on the first year EFL undergraduate EFL students writing achievement. The reached population of this research is the first year undergraduate EFL students of the 3 chosen private and public universities in East and Central Java. Using GEFT Instrument, all the first year EFL students of those universities are tested and those students classified as field independent cognitive style only used as the subject of experimentation. Others having neutral and field dependent cognitive style are used as comparative groups. Posttest only design with 5 meetings using simplified product oriented writing instruction procedure treatment are applied to those subject. The finding shows that there is a significant betterment of the subject writing achievement after being given product oriented writing instruction. The reason of why the field independent cognitive style EFL students are more superior that the other two is because the learners having Field Independent Cognitive Style treat information and model as the characteristics of product oriented writing instruction as an independent part of his environment/surrounding, whereas the learners having other cognitive style treat information and perception as a whole and not separated from his environment/the surrounding. That makes the subject can take the advantage of the model and example presented in product oriented writing instruction. The researcher recommends TEFL practitioners consider the learner's characteristic (cognitive style) as one of the learning condition variables that must be used as the base to determine the teaching/learning method to get the optimum learning achievement. Product oriented teaching in writing is suitable to be given for the students having field independent cognitive style.
\end{abstract}

Keywords: product - oriented writing, field independent cognitive style, writing achievement

\section{INTRODUCTION}

This In the area of learning English as a foreign language (EFL) and English as a second language (ESL) where four common basic skills; listening, speaking, reading and writing are required to the students to master, writing is considered the most difficult even most complicated skill. Writing skill is a complex and sometimes difficult to teach, requiring mastery of grammatical and rhetorical devices also conceptual and judgmental elements (Heaton, 1989; Latief, 1990; Sun, 2009). The complexity of writing is not only made up from the linguistic aspects, but also from organization and rhetorical aspects. In writing, the students are required to master then apply the English language rules in sentence level or grammatical elements. Besides, they have even to go beyond sentence level to reach rhetorical devices also conceptual and judgmental elements.

Referring to teaching writing approach, teaching writing issues and practices have been familiar with product and process approach. Product and process approaches refer to different notion. A product approach is an instructional program emphasizing on the quality of the students' writing outcomes. In the product approach, the writing teachers usually treat students' composition as a finished product. Therefore they respond and evaluate that product. Productoriented approach focuses on grammatical and discourse levels, looking at error, fluency (length), writing quality, and structure. It is looking at whole texts in terms of their coherence, stylistics, and culture (Furneaux, 1999).

According to Hedge (2003) there are some implications of giving product oriented writing instruction to students' writing. The implications are: to helping students identify their writing needs; to building awareness of discourse organization; to helping the students develop their skills; and to enable students appreciate the criteria for an effective text. As proposed by him this approach which would be valuable to students university students needing to produce a range of expository essay in English for example making comparison and contrast systems, discussing problems and some possible solutions, or making review of an argument critically.

In the effort of increasing students' achievement by applying chosen and determined approach or method is really important. However, more important is making sure that the very method or approach is really required by the students. It is not infrequent for the teacher not taking account the unique of the students he teaches. A method supposed to be the most effective method for the learner in a certain condition does not frequently fit with the learner with other condition.

Applying a prospective method without scrutinizing its suitability with the learner's unique characteristic will not yield the optimum learning outcome. The learner characteristic should be given attention to get the optimum gain in the process of teaching learning. According to Weimer and Cassidy (2004) research on learner characteristic now spans four decades. The amount of work focusing on the issue flows recently. One of the learning characteristics is cognitive style. Cognitive style is important because it is the education relevant expressions of the uniqueness of the individual.

In the area of second/foreign language acquisition, cognitive style has received great attention. Freeman and Long (1991) reported that there was a finding of study about the correlation between SL (second language) achievement and cognitive style and 
the link between field independence (one kind of cognitive styles) and communicative competence. In more recent time, some attempts to study cognitive style in the area of EFL/ESL have been also conducted. Bachman (1990) in studying the ability of the learner with certain kind of cognitive style in doing integrative tests such as the cloze and the oral interview. In another study, Chapelle and Roberts (1992) reports significant correlation between field-independence (one type of cognitive styles) and cloze test in adult ESL students. To summarize there many scientific reasons based on research stating that cognitive style is proved to be one of the important variables determining the success of mastering language skill.

Not wanting to be left behind, this study in some extent attempts also to investigate the cognitive style in conjunction with teaching writing orientation in the effort of boosting the EFL students in performing better in writing skill. Since writing is decidedly a cognitive process (Hormazábal, 2007), studying cognitive style together with studying teaching writing approach is really appropriate. Cognitive skill is one of pedagogy theories, but it has been initially examined in applied linguistic area. A linguist, Johnson (2001) has asserts that the teacher should give attention to students' cognitive learning in language teaching.

By the above rationale, this study is carried out on the basis of two main reasons; the first, there are still many EFL learners, at the first year of writing class, who still get difficulty in making writing composition argumentative, hence finding the best teaching approach in writing among other existing approaches that can foster students' writing achievement is really is really in need. This study for some extent is aimed at this goal. Besides, there has not been a research conducted to examine the suitability between teaching approach (product oriented) in writing and the students' characteristics which in this study is specified into cognitive style to boost their achievement.

Therefore, based on that need, conducting the study aimed at finding the proof about whether there is any effect of applying product oriented teaching in writing instruction as one of the some approaches on the third year EFL learners with different cognitive style on students' writing achievement is really in great necessity.template, modified in MS Word 2007 and saved as a "Word 97-2003 Document" for the PC, provides authors with most of the formatting specifications needed for preparing electronic versions of their papers.

All standard paper components have been specified for three reasons: (1) ease of use when formatting individual papers; (2) automatic compliance to electronic requirements that facilitate the concurrent or later production of electronic products; and (3) conformity of style throughout a conference proceedings. Margins, column widths, line spacing, and type styles are built-in; examples of the type styles are provided throughout this document and are identified in italic type, within parentheses, following the example. Some components, such as multi-leveled equations, graphics, and tables are not prescribed, although the various table text styles are provided. The formatter will need to create these components, incorporating the applicable criteria that follow.

\section{Procedure}

\section{MethodS}

The complete procedure of this study is as follows; first, the available research subjects from the three universities were assigned independently into three classifications based on their cognitive style. The assignment was conducted by administering a cognitive test called GEFT/Group Embedded Figure Test (Witkin, et. al., 1971). By administering this instrument, the research subjects from the three institutions were divided into three groups on the basis of their cognitive style from the score gained of the GEFT administered. Based on the consideration above, for the sake of obtaining the data needed for this research, they are data about subjects' cognitive style, Instrument GEFT is used. In GEFT, subjects are asked to recognize and identify some simple objects from complicated patterns in which a simple object hidden.

The easier a subject is able to recognize those simple objects hidden in the complicated pattern, the higher score he can achieve. In this case he is classified as having field independent cognitive style. In contrast, the more difficult a subject to recognize those simple objects hidden in the complicated pattern, the lower score he can achieve. In this condition, he is classified as field dependent cognitive style student. In other words, those who have field dependent cognitive style tend to be very sensitive to "gestalt like" activity (Niaz, 1987). Since this (GEFT) instrument is a standardized test that is not constructed by the researcher, its validity and reliability have been measured and guaranteed.

This instrument has two sections. The first section is test instruction and exercise. The second section consists of test in three parts. Every part contains picture-test items. The first part (PART I) consists of 7 items. The second part (PART II) consists of 9 items. The third part (PART III) consists of 9 items. Time allocation to do the test for every part is 10 minutes. Score for every item is 1 (one) point. The maximum score achieved by the subjects after finishing doing the test is 18 point. The classification of the subjects' cognitive style is like the following: (1) the subjects who achieved test score ranging from 0-6 are categorized as field dependent cognitive style (FDC) subjects; (2) the subjects who achieved test score ranging from 7-12 are categorized as neutral cognitive style subjects; and (3) the subjects who achieved test score ranging from 13-18 are categorized as having field independent cognitive style subjects.

The administration of the GEFT to the three institutions yielded the following classification. The third year English Language Department students of Kanjuruhan University consisting of 249 subjects were classified into 59 students in field independent cognitive style group, 105 students in field dependent cognitive style group and 85 in neutral cognitive style group). Islamic University of Malang with 180 students were classified into 97 students in field dependent 
cognitive style group, 50 students in neutral cognitive style group and 33 students field independent cognitive style group. Whereas from IAIN Surakarta with 175 students it could be obtained 75 students in field dependent cognitive style group, 57 students in neutral cognitive style group and 43 students field independent cognitive style group.

Next, those three big groups with three different cognitive styles in every in every institution independently were selected using stratified random sampling to get 90 students in every institution as sample. The sample that have been classified into three groups of cognitive style was randomly assigned further into three groups for each that eventually result in three groups having field dependent cognitive style, three groups having neutral cognitive style and three groups with field independent cognitive style.

Prior to the treatment, pre-test was given to all research subject groups. Pre test was administered in the first meeting. The subjects were given writing prompt with the certain topic to write an argumentative composition. The total time allocation to do the test is 90 minutes. The students' compositions as the result of the pre test were scored using the table of categories of ESL Composition Profile by the rate team. The scores of the pre test yielded were analyzed using SPSS 1.2 Pearson Product Moment correlation in order to make sure that the subjects arranged in research shows groups are in similar condition before treatment. The result of the analysis shows that the group of the subjects had significantly positive correlation at $\mathrm{p} 0.05$. It signifies that the groups of subjects before treatment were in similar condition.

\section{Treatment}

Treatment in the form of giving differential orientation in writing instruction was applied to all those nine experimental group research subjects. The total of the meetings required to conduct of the study were 8 ( $2 \times 50$ minutes in every meeting). 1 meeting was consumed for administering GEFT instrument to assign the subjects' cognitive style, 1 meeting was used for administering pre-test. Treatment was given to the subjects in 6 meetings constituted in three lesson plans. The last lesson plan was applied together with the preparation of post test. It was conducted by the reason of fulfilling the steps of product, multidimensional and process oriented teaching writing requirement. In the period of treatment, the researcher acted as lecturer who led, facilitated and supervised every research group in the writing classes.

After treatment was already implemented completely, the post test was administered to the subjects of all groups. The post test was administered in the $8^{\text {th }}$ meeting. The last two meetings arranged in one lesson plan (the $7^{\text {th }}$ meeting and the $8^{\text {th }}$ meeting) were deliberately dedicated to produce the last composition for post test. The subjects' compositions from the post test were scored by using a ready-made scoring guide called ESL Composition Profile developed by Jacobs, Zinkgraf, Wormuth, Harfiel, and Hughey (1981).

\section{RESUlt AND Discussion}

The following is the description of writing achievement of the field independence, neutral and field independence cognitive style subject group after given product oriented writing and comparison of the all research subjects' writing achievement across the cognitive styles.

\section{Writing Achievement of the Field Independence Cognitive Style Subject Group After Given Product Oriented Writing Teaching}

The students in the group of field independence after taught using product oriented writing achieved 55.0 as the lowest score and 85.0 as the highest score from 100 as the maximum and 0 as the minimum. The range score of this group is quite wide that is 30.0 showing that the difference between the unskilled student and the skilled student in this group is quite far. The mean score of this group is 75.983 with standard deviation 8.0263 and variance 64.422 showing that the students' scores in this group is widely distributed. Yet, if it is compared with the scores before treatment, the width of the distribution decreases.

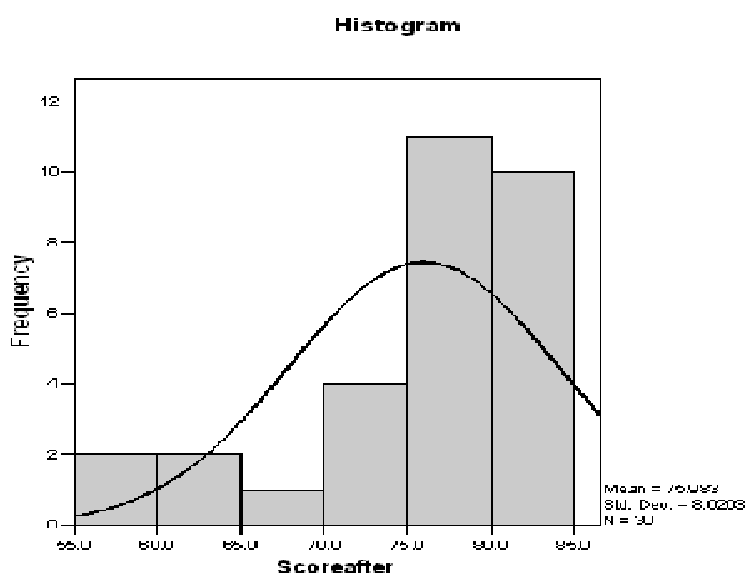

Figure 1

Histogram of After Treatment Scores of Writing Achievement of the Field Independent Cognitive Style Subject Group 
The after treatment scores distribution of argumentative achievement of the field dependenceproduct oriented group is represented by using the above histogram. The histogram is negatively skewed, with the value is relatively high that is -1.234 meaning that the number of the students in this group achieving the scores below the mean is more those who achieve the scores above the mean.

\section{Writing Achievement of theNeutral Cognitive Style Subject Group After Given Product Oriented Writing Teaching}

The group of neutral product oriented students before after using multidimensional oriented writing achieved the 51.0 as the lowest score and 76.0 as the highest score from 100 as the maximum and 0 as the minimum. The range score of this group is 25.0. The range is not quite wide showing that the difference between the unskilled student and the skilled student in this group is quite not far. The mean score of this group is 62.550. Whereas, the standard deviation is 7.9841 and variance is 62.316. It means that the distribution of students' scores in this group is not as varied as before.

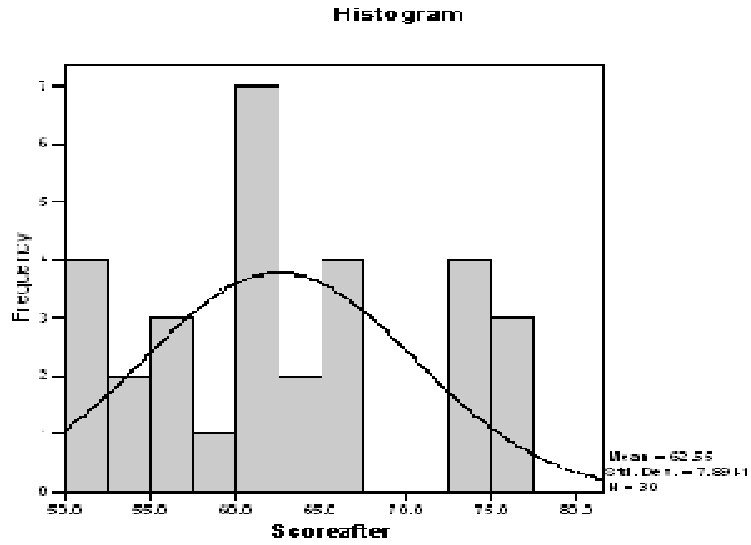

Figure 2

Histogram of After Treatment Scores of Writing Achievement of the Neutral Cognitive Style Subject Group

Writing Achievement of the Field Dependence Cognitive Style Subject Group After Given Product Oriented Writing Teaching

The following is the After Treatment Scores of Argumentative Achievement of the Field Dependence Cognitive Style-Product Oriented Group. The table below summarizes the result of analysis. The highest score achieved by the students in the group is 75.5 and the lowest score is 51.0. The range is 34.5. The mean score of this group is 61.567. The standard deviation of this group is 7.2156 and the variance is 52.064. The value of the standard deviation in this group is smaller than before treatment indicating that the homogeneity of the scores increases.

Figure 3 describes the after treatment scores of argumentative achievement of the students in the group of the field dependent-product oriented. The skew of the histogram is at .370 , small enough, meaning that the scores of the students in this group are normally distributed. In other words, the number of the students achieving the scores below the mean and above the mean is relatively equal.

llistogram

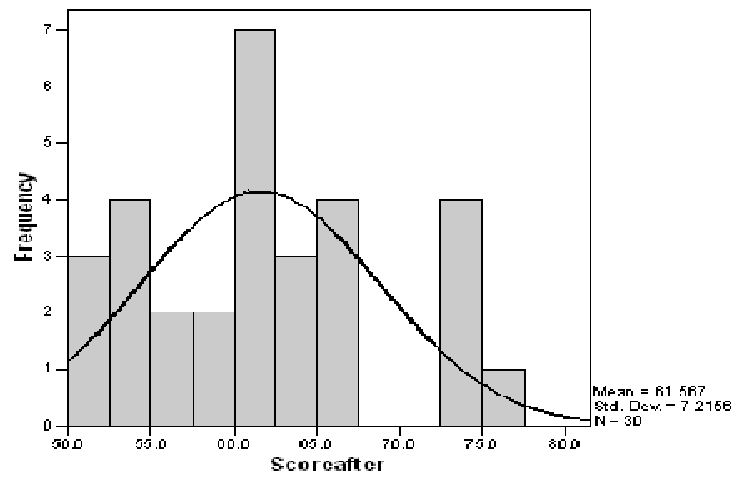

Figure 3

Histogram of After Treatment Scores of Writing Achievement of the Field Dependent Cognitive Style Subject Group 


\section{Comparison of the Subjects' Writing Achievement after Treatment across the Cognitive Styles}

The F-ratio for cognitive style is 3.625 with the degrees of freedom 2. The $\mathrm{P}$-value is .028. The significance level used in this research is $.05(\alpha=.05)$. This P-value is less than $\alpha$. Therefore, it is found that there is a significant difference between the writing achievement of the subjects in three different cognitive style group (field independent cognitive style, neutral cognitive style and field dependent cognitive style) after being treated using product oriented teaching. Table 1 shows that the mean of student's argumentative achievement after in the group of field independent cognitive style is 70.156. Mean of the neutral cognitive style group is 69.411 and the mean of field dependent cognitive style group is 66.844 . Interval score of the first group is from 3.233. The second group's interval score is 3.593 and the last group's interval score is 3.593. Arranged accordingly based on the rank among the three groups, the highest position is achieved by field independent cognitive style group. The second is neutral cognitive style group and the last is field dependent cognitive style group.

Table 1

Estimated Marginal Means of Subjects' Writing Achievement in three Different Cognitive Style Groups

Dependent Variable: Score Of Writing Test

\begin{tabular}{lcccc}
\hline \multirow{2}{*}{ Cognitive Style } & \multirow{2}{*}{ Mean } & Std. & \multicolumn{2}{c}{ 95\% Confidence Interval } \\
\cline { 5 - 6 } \cline { 5 - 6 } & & Error & Lower Bound & Upper Bound \\
\hline 1 = Field Independent Cognitive Style & 70.156 & .912 & 68.359 & 71.952 \\
2 = Neutral Cognitive Style & 69.411 & .912 & 67.615 & 71.208 \\
3 = Field Dependent Cognitive Style & 66.844 & .912 & 65.048 & 68.641 \\
\hline
\end{tabular}

After considering the above empirical fact above, one important question challenging to discuss is concerning with why the students having field independent cognitive style have tendency to have higher achievement in making argumentative composition than the neutral cognitive style group and the field dependent cognitive style group. This question is in need to be verified. The more general interesting and important question needs also to discuss preceding the more specific one above is about how cognitive style owned by the students helps affecting the argumentative composition achievement.

As has been explained before, cognitive style is defined the habit to act relatively constant inside of a person to receive, think, solve and recall/memorize information Cognitive style is characteristic about how a person receives, organizes and stores the information. It concerns also with how a learner receives, interacts and responds his learning environment (Keefe, 1987); Witkin, et al., 1971; Diptoadi, 1990). The reason of why cognitive style affects students' writing achievement is explained by the following.

Writing is a cognitive process, and the steps involved in this cognitive process may be identified when some of the strategies used by the students are revealed (Hormazábal, 2007). Since it is cognitive process, writing activity is complex problem-solving activity, responding to a rhetorical situation in the form of a text. Their work, largely known as cognitive process model, represented the internal process of the writer's mind and looks at composing as a complex problem-solving activity Flower and Hayes (1981).

The next hard task should be done after knowing the above fact is verifying the possible yet scientific reason of why the students having independent cognitive style is more superior in writing argumentative composition than the students having neutral and dependent cognitive style. As asserted by some scholars, the learner having Field Independent
Cognitive Style treats information and perception as an independent part of his environment/surrounding, whereas the learner having Field Dependent Cognitive Style treats information and perception as a whole and not separated from his environment/the surrounding. A person having FD cognitive style usually gets the difficulty to separate a concept or a perception from the surrounding context. It will results in the unclear and unassimilated information receiving. FD learner tends to view a concept or a problem as a whole (global approach). FD learner will face a problem as a confusing whole, without seeing the component inside that can be used to help solving the problem more quickly (Keefe, 1987; Witkin, et al., 1971; Diptoadi, 1990).

As has been proposed by Hormazábal (2007) writing, especially writing argumentative composition is a cognitive activity. As it is cognitive, the activity requires a complex problem-solving activity. It also requires responding to a rhetorical situation in the form of a text. Their work, largely known as cognitive process model, represented the internal process of the writer's mind and looks at composing as a complex problem-solving activity Flower and Hayes (1981). The activity is so complicated, during the process of making composition in which the students are continuously making evolving, proposing the argumentation, rejecting ideas and thereby making it a dynamic practice of composition involving plans and development. In doing the activity, the students having Field Independent Cognitive Style who can separate a concept or a perception from the surrounding context will get advantage. It is because the ability to separate a concept or a perception from the surrounding context will results in the clear and assimilated information receiving.

They have also the ability to see the component inside that can be used to help solving the problem quickly. Besides, Field Independent EFL learners have 
a tendency to restructure the environment/context given with the dominant organization. Other favor given to the students having Field Independent Cognitive Style is related to their analytical skill. Saracho states that students having Field Independent Cognitive Style have strong analytic skills (Freeman and Long, 1991). Similarly, Hansen \& Stansfield (1981); Chapelle \& Roberts (1986) also state that field independent learners easily separate key details from a complex or confusing background, while their field dependent peers have trouble doing this. Field independent learners show significant advantages over field dependent learners in analytical tasks. Those are required very much in making argumentative composition. Hence, their achievement in writing argumentative composition is fostered.

On the other side, the EFL learner having Field Dependent Cognitive Style treats information and perception as a whole and not separated from his environment/the surrounding. Field dependent EFL learners have a tendency to follow the environment or the context given. A person having field-dependent cognitive style usually gets the difficulty to separate a concept or a perception from the surrounding context. It will results in the unclear and unassimilated information receiving.

A field dependent learner tends to view a concept or a problem as a whole (global approach). A field dependent learner will face a problem as a confusing whole without seeing the By having such kind of limitation EFL learners get a much more barrier in writing argumentative composition that results in the lower achievement compared with the EFL learner having Field Independent Cognitive Style. For the EFL learner having neutral cognitive style, it is not an urgency to explain the theoretical reason, since it can be predicted easier than the two extreme poles. It becomes clear merely by saying that the EFL learner having neutral cognitive style is the combination between the two or a half from one a half from another.

In the USA, Hansen and Stanfield (1981) found that field-independence play a major role in the acquisition of linguistic competence for American college students enrolled in a Spanish course. The same researchers also found a positive but rather modest link between field-independence and satisfactory scores on cloze tests, with a similar group of adult learners. Chapelle and Roberts (1986), in a study conducted with adult ESL learners in an American university, discovered that field-independence predicted success for this group on traditional tests of an analytic nature. In another study of the importance of fieldindependence, Abraham (1985) investigates the possible relationship between field-dependence / independence and the teaching of grammar.

She claims that her study provides insights into how students along one continuum of individual differences (i.e. that of cognitive style) internalize knowledge about one grammatical item in a second language. Chapelle and Robert (1986) relates fielddependence/independence to language testing by considering this issue as a source of variance in language tests. For the justification of her study, she claims that recent language testing research investigates factors other than language proficiency that may be responsible for variance in language test performance.

There is some evidence indicating fieldindependent may be one variable responsible for introducing systematic error into language test scores. In her study, Chapelle reports research investigating the relationship between field-independence and language measures. The results of her study, she claims, indicate differential relationships of fieldindependence with cloze, dictation, and multiplechoice language tests. The relative strengths of these relationships also differed for native speakers in regular English classes, native speakers in remedial English classes, and non-native speakers.

Most of the available evidence offers support for a relationship between field independence and second language learning success. One disturbing consequence of the relationship is that both field dependence and field independence have been linked with second language success, but the former is usually thought to be something a field dependent person is more likely to exhibit. Brown offers an explanation that we have evoked before to explain other such conflicts. He suggests that field independence may be important to classroom learning and to performance on paper and - pencil tests; however, when it comes to untutored SLA, field dependence may be more beneficial because successful SLA will be determined by how well the learner can communicate with speakers of the TL (target language), and emphaty will help in this regard (Freeman and Long, 1991). It is interesting to note that of their three measures of language proficiency. Hansen and Stanfield found the weakest link between field independence and communicative competence (Freeman and Long, 1991).

Referring to the teaching approach matched with the students' characteristic, the finding of this research explicitly reveals that product oriented teaching in writing is effective in increasing the writing achievement if it is given to EFL students' with independent cognitive style. The EFL students with field independent cognitive style are not recommended to be given teaching writing orientation other than product oriented. Otherwise it will make their achievement decreased. Product oriented teaching in writing is suitable to be given for the learners who have field independent cognitive style.

Field Independent learners have a tendency to restructure the environment/context given with the dominant organization different from the field dependent learners who have a tendency to follow the environment or the context given. Instead of preferring the teaching approach having the steps like process approach that make them lose of focus, the comprehensive modeling approach strengthens their analytical capability. Their ability to see the component inside that can be used to help solving the problem quickly can be build by comprehensive modeling approach.

The comprehensive modeling approach is also able to develop their tendency to restructure the 
environment/context given with the dominant organization. Since students having Field Independent Cognitive Style (FI) have strong analytic skills and have ability easily separate key details from a complex or confusing background by themselves that are required very much in making argumentative composition, giving them teaching approach that enables them to work individually makes their achievement in writing argumentative composition fostered.

\section{Conclusion}

Based on the research evidence and discussion described in the previous chapter, the followings are the conclusions. The students having field independent cognitive style achieve high achievement when they are given product oriented teaching in writing. The empirical fact implies that the students prefer teaching approach differently as they have different cognitive style. The students with different cognitive style have different preference to the teaching orientation or approach given to them. The students with field independent cognitive style prefer product oriented teaching to boost their achievement.

Field-dependence and field-independence, the kinds of cognitive style as one of the characteristics the language learners have are differentially related to formal-linguistic and functional-communicative foreign language learning tasks or situations. As cognitive style really affects both achievement and proficiency in writing course, educators should implement ways of drawing on this factor in formal language education. They should have awareness and different expectation to the students that may have different kind of cognitive style.

In the teaching writing course the teacher should assign the students as their style and the teaching approach they give to the students should be the one that has been adjusted to the students' preference. Any approach in teaching writing course is good only if it is given to the students having the learning characteristic/style suitable with the procedure of applying the approach in teaching writing. Giving writing approach forcefully to the students who do not really require as their cognitive style is in contradictory with it will sacrifice the students' performance, wasting time and useless.

\section{REFERENCES}

[1] Abraham, R. G. 1985. Field Independence-Dependence and the Teaching of Grammar. TESOL Quarterly, 19(4), 698-702.

[2] Bachman, L. F. 1990. Fundamental Considerations in Language Testing. Oxford: Oxford University Press.

[3] Chapelle, C., \& Roberts, C. 1986. Ambiguity Tolerance and Field Independence as Predictors of Proficiency in English as a Second Language. Language Learning, 36, 27-45.

[4] Diptoadi, V. L. 1990. Pengaruh Cara Penyampaian Bacaan dengan Menggunakan Advance Organizers dan Daftar Kata Pokok terhadap Perolehan Membaca Mahasiswa Jurusan Bahasa Inggris yang Memiliki
Karakteristik Berbeda. Disertation. Malang: IKIP Malang.

[5] Flower, L. S., and Hayes, J. R. A. 1981. Cognitive Process Theory of Writing. College Composition and Communication, 32(4): 365-387.

[6] Furneaux., C. 1999. Recent Materials on Teaching Writing. ELT Journal, 53(1).

[7] Hansen, J., \& Stansfield, C. W. 1989. The Relationship of Field Dependent-Independent Cognitive Styles to Foreign Language Achievement. Language Learning, 31, 349-367.

[8] Heaton, J. B. 1989. Writing English Language Tests. London: Longman.

[9] Hedge, T. 2003. Teaching and Learning in the Language Classroom. Oxford: University Press.

[10] Hormazábal, R. D. 2007. Argumentative Writing Strategies and Perceptions of Writing in Academia by EFL College Students. Literatura Lingüística, 18, 253282.

[11] Jacobs, H., Zinkgraf, S. A, Wormuth, D. R., Hartfiel V. F., and Hughey, J. G. 1981. Testing ESL Composition: A Practical Approach. Massachusetts: New House Publishers, Inc.

[12] Johnson, K. 2000. An Introduction to Foreign Language Learning and Teaching. London. Pearson Education Limited.

[13] Keefe, J. W. 1987. Learning Style: Theory and Practices. New York: Reston NASSP.

[14] Larsen-Freeman, D. L 1980. Discourse Analysis in Second Language Research. Massacussetts: Newbury House Publishers, Inc.

[15] Latief, M. A. 1990. Assessment of English Writing Skills for Students of English as a Second Language at IKIP MALANG Indonesia. Dissertation. Iowa: The University of Iowa.

[16] Niaz, M. 1987. The Role of Cognitive Factor in Teaching Science. Research in Science and Technology Education, 5(1), 7-16.

[17] Sun, S. 2009. Process Approach to Teaching Writing Applied in Different Teaching Model. English Language Teaching Journal, 2(1).

[18] Weimer, Maryellen, and Cassidy, S. 2004. Learning Styles: An Overview of Theories, Models, and Measures. Educational Psychology, 24(4), 419-444.

[19] Witkin, H. A., Oltman, P. K., Raskin, E., and Karp, S. A. 1971. A Manual for the Embedded Figures Test. Palo Alto: Consulting Psychologist Press, Inc. 